\title{
PALEOPRODUCTIVITY VARIATIONS IN THE EQUATORIAL ARABIAN SEA: IMPLICATIONS FOR EAST AFRICAN AND INDIAN SUMMER RAINFALLS AND THE EL NIÑO FREQUENCY
}

\author{
Manish Tiwari ${ }^{1,2} \bullet$ Rengaswamy Ramesh $^{1} \bullet$ Ravi Bhushan $^{1} \bullet$ B L K Somayajulu ${ }^{1} \bullet$ \\ A J Timothy Jull ${ }^{3} \cdot$ George S Burr ${ }^{3}$
}

\begin{abstract}
We analyzed a sediment core from the equatorial Arabian Sea, chronologically constrained by accurate accelerator mass spectrometry (AMS) radiocarbon dates on selected planktonic foraminiferal species, for paleoproductivity variations corresponding to the variations in the Indian Ocean Equatorial Westerlies (IEW). The IEW in turn are positively correlated to the Southern Oscillation Index (SOI), which is a measure of El Niño, Southwest monsoon (SWM), and east African rainfall (EAR). The productivity data show that Indian and east African rainfalls declined from 35,000 calendar yr BP up to the last glacial maximum (LGM), with the maximum El Niño frequency during the last glacial period. From 14,500 to 2000 calendar yr BP (i.e. core top), we find strengthening SWM and EAR along with declining El Niño frequency.
\end{abstract}

\section{INTRODUCTION}

The equatorial/southern Arabian Sea is the least studied region of the Indian Ocean, as most of the earlier paleomonsoon studies have focused on either the western/northern or eastern Arabian Sea (e.g. Morrill et al. 2003 and references therein). Furthermore, the South Asian monsoon (Southwest monsoon, SWM, and Northeast monsoon, NEM) periods have received much attention since they involve planetary-scale atmospheric and hydrospheric changes. In contrast, the monsoon transition periods in April-June and September-November have not been studied in detail, although they are the main rainy seasons for eastern Africa and feature a short-lived but intense upper oceanic jet in the equatorial Indian Ocean (Wrytki 1973; O'Brien and Hulburt 1974; Hastenrath et al. 1993). In the equatorial Indian Ocean, winds are strongest during April-November with maximum variability during the monsoon transition periods, namely April-June and October-November. These winds are termed the Indian Ocean Equatorial Westerlies (IEW; in contrast, in the rest of the Indian Ocean, winds reach their maximum intensity during the SWM or NEM). The IEW cause short-lived but intense eastward upper-ocean water currents termed Eastward Equatorial Jets (EEJ) (Wrytki 1973; Schott and McCreary Jr. 2001; Hastenrath et al. 1993; Beaufort et al. 1997). The strong variability during the monsoon transition period is the result of strong wind bursts capable of causing deeper mixing of the surface water. Therefore, maximum productivity in this region occurs during the intermonsoon periods (McIntyre and Molfino 1996; Beaufort et al. 1997). The IEW are the result of the Walker circulation and exhibits a positive correlation with the Southern Oscillation Index (SOI), a measure of the intensity of the Walker circulation/El Niño events (Bjerkness 1969; Hastenrath et al. 1993). El Niño affects the Indian monsoon in the way that the rising limb of the Walker circulation and the tropical convection, which is usually located in the western Pacific, shift towards the central and eastern Pacific. This shift results in subsidence over the western Pacific and the Indian subcontinent, which suppresses convection and precipitation over the Indian landmass (Pant and Parthasarthy 1981; Rasmusson and Carpenter 1983; Ropelewski and Halpert 1987). The high Southern Oscillation (SO) phase is related to a low El Niño activity and hence a strengthened Indian SW monsoon (Hastenrath et al. 1993). Moreover, eastern Africa possesses 2 rainy seasons. The first, which is more abundant in terms of rainfall, occurs during March-June with its core around April-May (called the "long rains" in Kenya and "Gu" rains in Somalia). The second season occurs from September-November and exhibits more interannual variability in precipitation, with its core around

\footnotetext{
${ }^{1}$ Planetary and Geosciences Division, Physical Research Laboratory, Ahmedabad, 380009 India.

${ }^{2}$ Corresponding author. Email: tmanish@ prl.res.in.

${ }^{3}$ NSF Arizona AMS Facility, University of Arizona, Tucson, Arizona, 85721 USA.
} 
October-November (called the "short rains" in Kenya and "Der" rains in Somalia). High correlation of these rainfalls with the SO phase have been reported by various authors. During the high SO phase, enhanced "long rains" have been found by several authors (e.g. Hastenrath et al. 1987; Bhatt 1989; Beltrando and Camberlin 1993; Ogallo et al. 1998) and strengthened "short rains" have been reported by Van Heerden et al. (1988), Martarira (1990), and Walker (1990). Thus, past variations in the intensity of the IEW can be related to past fluctuations in the El Niño/SOI, Indian summer monsoon, and east African rainfall. A sediment core (SS3827G) was raised from the equatorial Indian Ocean that can help in documenting past variations in the oceanic and atmospheric conditions during the intermonsoon periods.

\section{MATERIALS AND METHODS}

SS3827G is a gravity core with a total length of $196 \mathrm{~cm}$. It was recovered during R/V Sagar Sampada cruise nr SS152 in 1997 from a water depth of $3118 \mathrm{~m}$, and thus represents an open-ocean regime. Its location is east of the Maldives Islands at $3^{\circ} 42^{\prime} \mathrm{N}$ and $75^{\circ} 54.5^{\prime} \mathrm{E}$ (Figure 1).

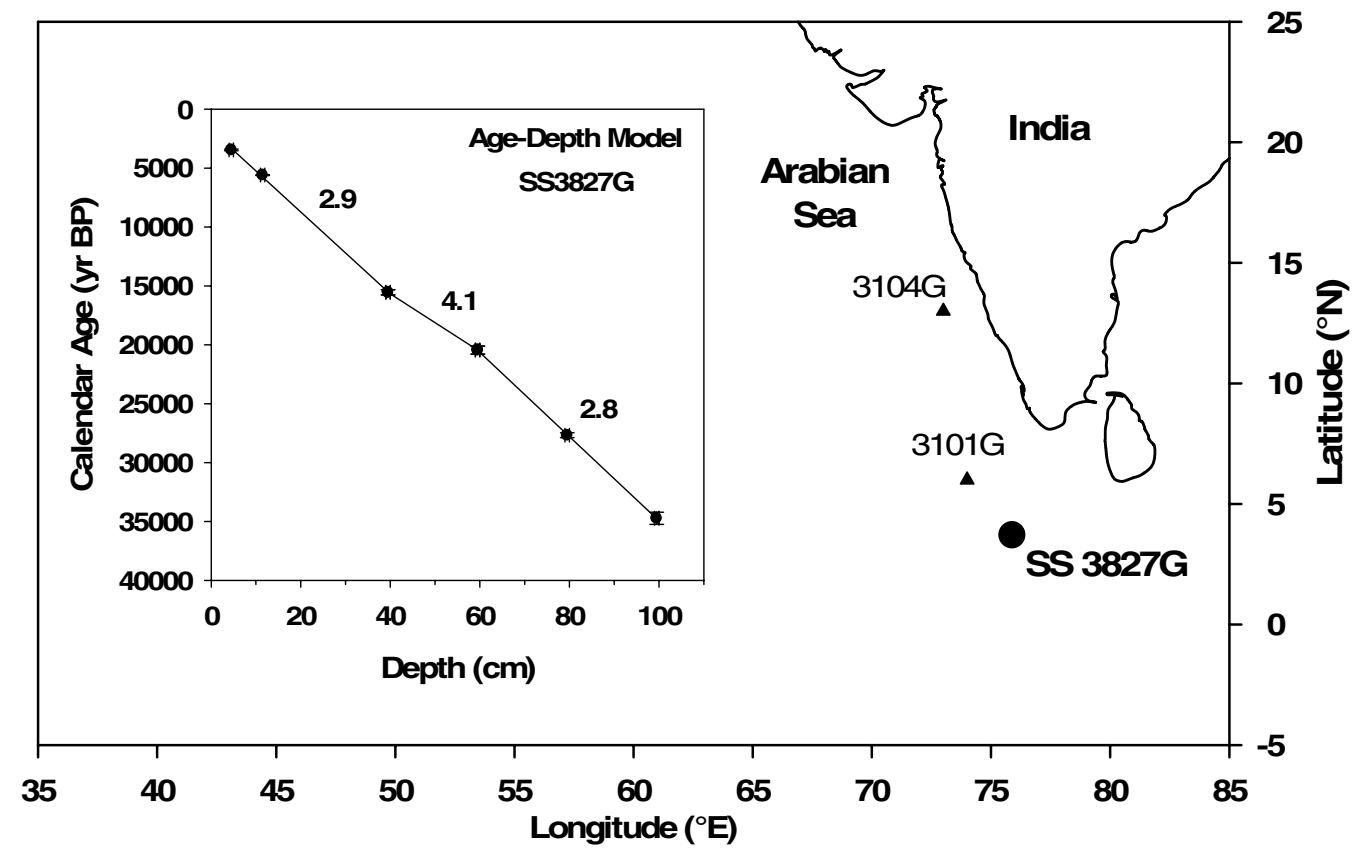

Figure 1 Locations of the core SS3827G and other cores (depicted by triangles) with which it has been compared; inset: calibrated ${ }^{14} \mathrm{C}$ ages and sedimentation rates $(\mathrm{cm} / \mathrm{kyr})$ for the core $\mathrm{SS} 3827 \mathrm{G}$.

In this core, 6 accelerator mass spectrometry (AMS) radiocarbon dates were obtained on planktonic foraminiferal separate, namely Globigerinoides ruber, Globigerinoides sacculifer, Orbulina universa, and Neogloboquadrina dutertrei, spanning the past 34,700 $\pm 500 \mathrm{cal}$ yr (inset, Figure 1). The size range $250-500 \mu \mathrm{m}$ was chosen, but care was taken to pick shells predominantly falling in the size range $300-400 \mu \mathrm{m} . \mathrm{CO}_{2}$ was evolved from the calcitic foraminiferal shells using phosphoric acid. The $\mathrm{CO}_{2}$ was then reduced to $\mathrm{CO}$ over hot zinc and was further reduced to graphite over iron fillings maintained at about $600{ }^{\circ} \mathrm{C}$. The graphite powder samples $(\sim 0.5 \mathrm{mg})$ were put into the target holder of the AMS and analyzed. ${ }^{14} \mathrm{C}$ dating was carried out using the accelerator mass spectrometer at the NSF Arizona AMS Facility, University of Arizona, USA (Linick et al. 1986; Jull et al. 1989). 
The total length of the dated core was $100 \mathrm{~cm}$. Thus, the average sedimentation rate was $\sim 3 \mathrm{~cm} / 10^{3}$ $\mathrm{yr}$, which is typical of open-ocean locations. The time resolution was approximately $350 \mathrm{yr} / \mathrm{cm} .{ }^{14} \mathrm{C}$ dates in this core have been calibrated using the calibration program Calib 4.1 (IntCal98, Stuiver et al. 1998) with a reservoir age correction of $500 \pm 30 \mathrm{yr}(\Delta \mathrm{R}=100 \pm 30 \mathrm{yr}$, Dutta et al. 2001; Southon et al. 2002). Refer to Table 1 below for the dates.

Table 1 Calibrated and uncalibrated ${ }^{14} \mathrm{C}$ dates obtained on selected species of planktonic foraminifera in core SS3827G with a reservoir age correction of $500 \pm 30 \mathrm{yr}$.

\begin{tabular}{llllcr}
\hline $\begin{array}{l}\text { Laboratory } \\
\mathrm{nr}\end{array}$ & $\begin{array}{l}\text { Depth in the } \\
\text { core }(\mathrm{cm})\end{array}$ & $\begin{array}{l}\text { Sample } \\
\mathrm{nr}\end{array}$ & $\begin{array}{l}\delta^{13} \mathrm{C} \\
(\%)\end{array}$ & $\begin{array}{l}{ }^{14} \mathrm{C} \text { age } \\
(\mathrm{BP})\end{array}$ & $\begin{array}{l}\text { Calibrated age } \\
(\mathrm{BP})\end{array}$ \\
\hline $\mathrm{T} 14775 \mathrm{~A}$ & $(4-5)$ & $\mathrm{AA} 43839$ & 1.33 & $3692 \pm 48$ & $3460 \pm 70$ \\
$\mathrm{~T} 14776 \mathrm{~A}$ & $(11-12)$ & $\mathrm{AA} 43840$ & 1.56 & $5338 \pm 52$ & $5590 \pm 40$ \\
$\mathrm{~T} 14778 \mathrm{~A}$ & $(39-40)$ & $\mathrm{A} 443842$ & 1.51 & $13,523 \pm 87$ & $15,550 \pm 220$ \\
$\mathrm{~T} 14779 \mathrm{~A}$ & $(59-60)$ & $\mathrm{A} 443843$ & 1.54 & $17,780 \pm 100$ & $20,450 \pm 340$ \\
$\mathrm{~T} 14780 \mathrm{~A}$ & $(79-80)$ & AA43844 & 1.76 & $24,040 \pm 180$ & $27,680 \pm 210$ \\
$\mathrm{~T} 14781$ & $(99-100)$ & AA43845 & 1.7 & $30,280 \pm 440$ & $34,730 \pm 510$ \\
\hline
\end{tabular}

In this study, several productivity proxies were measured, including $\mathrm{CaCO}_{3}(\mathrm{wt} \%), \mathrm{C}_{\mathrm{org}}$ (wt $\%$ ), and $\mathrm{C} / \mathrm{N}$ ratio in sedimentary organic matter, along with the $\delta^{13} \mathrm{C}$ of 3 species of planktonic foraminifera (G. ruber, G. sacculifer, and G. menardii). Higher organic productivity in the photic zone will enrich ${ }^{13} \mathrm{C}$ in the dissolved $\mathrm{HCO}_{3}{ }^{-}$and hence in planktonic foraminiferal shells. Microorganisms such as foraminifera and coccolithophores produce calcitic shells as a protective covering for their soft body, and the overhead rain of calcitic shells is a major constituent of the sea sediments. Thus, the calcium carbonate percentage in sea sediments can indicate the overhead productivity, provided the core has been raised from depths above the lysocline ( $3800 \mathrm{~m}$ in the Arabian Sea; Peterson and Prell 1985) and there is no contamination from the terrigenous inputs (Sirocko et al. 1993). Organic carbon $\left(\mathrm{C}_{\text {org }}\right)$ preserved in the sea sediments is derived from particulate organic carbon (POC) and is a manifestation of the overhead primary productivity if there are no alterations after the deposition (Muller and Suess 1979; Schulz et al. 1998). Organic matter in sea sediments can be from marine as well as terrestrial sources. It is therefore necessary to ascertain the source of the organic carbon before determining if its downcore variations are due to overhead surface productivity. The $\mathrm{C} / \mathrm{N}$ ratio of recent sediments comprising marine organic matter has a value of $8-10$, whereas the ancient sediments have a value of 12-15 (Mackenzie 1980). Terrestrial sources yield $\mathrm{C} / \mathrm{N}$ values between 20 and 100 (Premuzic et al. 1982; Meyers 1994). In this study, $\mathrm{C}_{\text {org }}$ was calculated by subtracting inorganic carbon values $\left(\mathrm{C}_{\text {inorg }}\right.$, calculated from $\mathrm{CaCO}_{3}$ content) from the total carbon values $\left(\mathrm{C}_{\text {total }}\right.$, measured using a $\mathrm{CN}$ analyzer), i.e. $\mathrm{C}_{\mathrm{org}}=\mathrm{C}_{\text {total }}-\mathrm{C}_{\text {inorg }}$. The precision percentages in measuring $\mathrm{CaCO}_{3}$, total carbon, and nitrogen were $3 \%, 4 \%$, and $6 \%$, respectively, while the precision of $\mathrm{C}_{\text {org }}$ was $5 \%$. All the uncertainties quoted are $1 \sigma$. Analytical precision for $\delta^{13} \mathrm{C}$ was $\pm 0.1 \%$. Burial fluxes for the $\mathrm{CaCO}_{3}$ and the organic carbon were calculated by multiplying the respective concentrations $(\mathrm{g} / \mathrm{g})$ with sedimentation rate $(\mathrm{cm} / \mathrm{kyr})$ and dry bulk densities $(\mathrm{DBD}, \mathrm{g} / \mathrm{cc})$. DBD were estimated using a non-linear regression equation based on samples that were free of ice-rafted debris (Clemens et al. 1987). Further experimental details are discussed elsewhere (Bhushan et al. 2001; Ramesh and Tiwari 2005). 


\section{RESULTS AND DISCUSSION: TEMPORAL VARIATIONS IN PRODUCTIVITY}

\section{Calcium Carbonate}

Since the core location is well away from land, i.e. in the open ocean, terrestrial input is negligible, and carbonate content observed at the core site is most likely to be of marine origin. The $\mathrm{CaCO}_{3}$ content of deep-sea sediments from the Arabian Sea was used to reconstruct past calcitic productivity variations in other studies, provided the core is raised from above the lysocline (e.g. Sirocko et al. 1993; Naidu and Malmgren 1999). The present core is well above the lysocline, which is at a depth of $\sim 3800 \mathrm{~m}$ in the equatorial Arabian Sea (Peterson and Prell 1985). In this core, $\mathrm{CaCO}_{3}$ concentration varies from 55 to $75 \%$ with a minimum during the LGM and a present maximum value (Figure 2). The burial flux varies from $10-18 \mathrm{~g} \mathrm{~m}^{-2} \mathrm{yr}^{-1}$, which closely matches the variation exhibited by $\mathrm{CaCO}_{3}$ concentration (Figure 2). This indicates that the burial flux is controlled by variations in the concentration, as the sedimentation rate stays more or less uniform. The productivity at the core site is due to the stress induced by the IEW (Beaufort et al. 1997). The wind-induced mixed-layer deepening would cause the deeper, nutrient-rich water to surface, thus causing the productivity to increase. Therefore, the productivity variation at the core site is a proxy for the strength of the IEW. The IEW, in turn, are positively correlated to the SOI (Hastenrath et al. 1993) and the Walker circulation, with implications for ENSO (El Niño-Southern Oscillation) variability (El Niño tends to occur in the low SO phase; e.g. Reverdin et al. 1986; Hastenrath et al. 1993). If this is the case, the equatorial Indian Ocean productivity records should exhibit a correlation with the eastern equatorial Pacific productivity records. In fact, Beaufort et al. (1997) have shown that the Maldives primary productivity-insolation phase is similar to that of the Pacific primary productivity records in the precession band, indicating the influence of the $\mathrm{SO}$ on both regions on a millennial time scale.

The calcareous productivity at the core site exhibits a decreasing trend from 35,000 calendar yr BP up to the LGM ( 21,000 calendar yr BP; Figure 2), indicating the uniformly decreasing strength of the IEW. At the LGM, we find the minimum calcareous productivity, signifying the minimum IEW strength. It implies that at the LGM the SOI was at its minimum, suggesting that at that time the Walker circulation had weakened considerably. The lower SOI further indicates that the SWM, as well as the EAR, weakened gradually up to the LGM, with their minimum values at the LGM. Thereafter, the calcareous productivity shows a slight increase from the LGM to 16,500 calendar yr $\mathrm{BP}$, which coincides with the early deglacial period. After this period, the calcareous productivity suffered a decline for the next $1000 \mathrm{yr}$, falling back to LGM values and indicating that IEW strength reduced considerably during that time. This decline implies a lower SO phase, i.e. reduced SW monsoon and east African rains at that time. A sharp increase in the calcareous productivity is seen at $\sim 14,500$ calendar yr BP, which coincides with the Termination IA, as recorded in the Greenland ice cores (Dansgaard et al. 1993; Grootes et al. 1993), pointing towards enhancement of the SWM and EAR during that time, along with a decrease in El Niño events. From then to 2000 calendar yr BP (i.e. core top), the productivity steadily increases, signifying a strengthening Walker circulation and thus a strengthening SWM and EAR and a lower El Niño frequency during the Holocene.

Paleomonsoon proxies from the western and eastern Arabian Sea have yielded contrasting results. For example, Gupta et al. (2003) have shown that SWM declined during the Holocene based on a single proxy, namely the declining abundance of G. bulloides (a planktonic foraminifera) in a core from the western Arabian Sea. In contrast, studies from the eastern Arabian Sea along the southwestern coast of India revealed that the SWM strengthened during the Holocene based on proxies such as oxygen and nitrogen isotopes (Sarkar et al. 2000; Agnihotri et al. 2003a). Tiwari (unpublished data) carried out a multi-proxy study in a core from the western Arabian Sea and reported an 


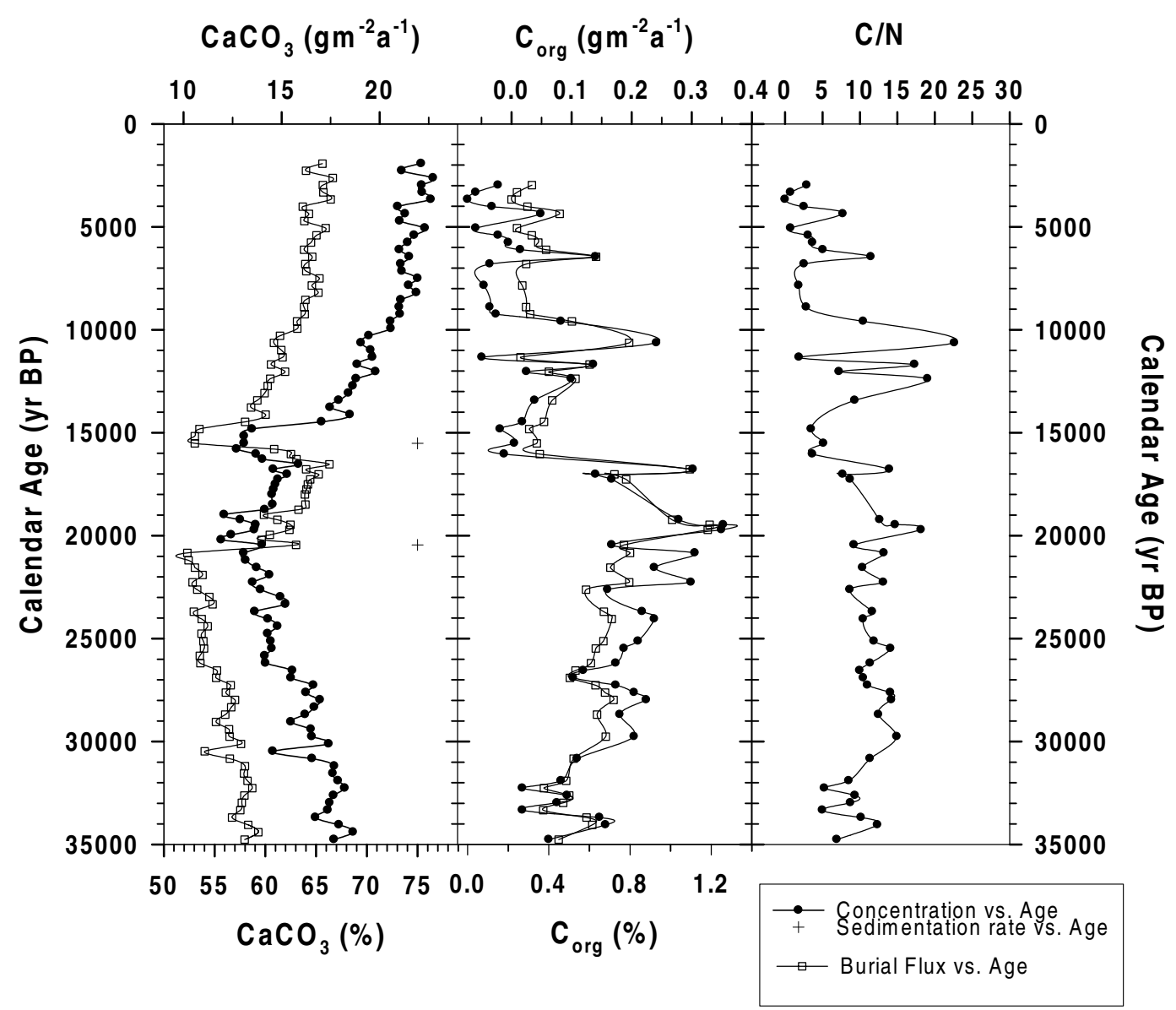

Figure 2 Downcore variations in the calcareous and organic burial fluxes, wt $\%$, and $\mathrm{C} / \mathrm{N}$ ratio in SS3827G. Open squares denote burial fluxes $\left(\mathrm{g} \mathrm{m}^{-2} \mathrm{yr}^{-1}\right)$, filled circles designate concentration (wt\%), and crosshairs in the first panel indicate the age at which the sedimentation rate changes.

increasing monsoon during the period. This study from the equatorial Arabian Sea reinforces the conclusion that the SWM enhanced during the Holocene.

\section{Regional Climatic Evolution: Comparison with the Eastern Arabian Sea}

The calcareous productivity record of SS3827G was compared with other such records to further explore the regional climatic conditions in the eastern and southern Arabian Sea. Agnihotri et al. (2003b) analyzed 2 cores from the eastern Arabian Sea, SS3104G and SS3101G (Figure 1), from water depths of $1680 \mathrm{~m}$ and $2680 \mathrm{~m}$, respectively. The chronologies of the cores were obtained by AMS ${ }^{14} \mathrm{C}$ dating on selected planktonic foraminifera species. They attributed the productivity variations to variations in the SWM strength. Figure 3 depicts the comparison of productivity variations in these 3 cores for the past 35,000 calendar yr BP.

All 3 cores exhibit more or less similar downcore variations in calcareous productivity, showing a decreasing trend up to the LGM (shaded area in Figure 3) from 35,000 calendar yr BP. It appears that both the SW monsoon winds and the IEW declined in tandem up to the LGM, suggesting that the 


\section{$\mathrm{CaCO}_{3}(\%)$}

$\mathrm{CaCO}_{3}(\%)$

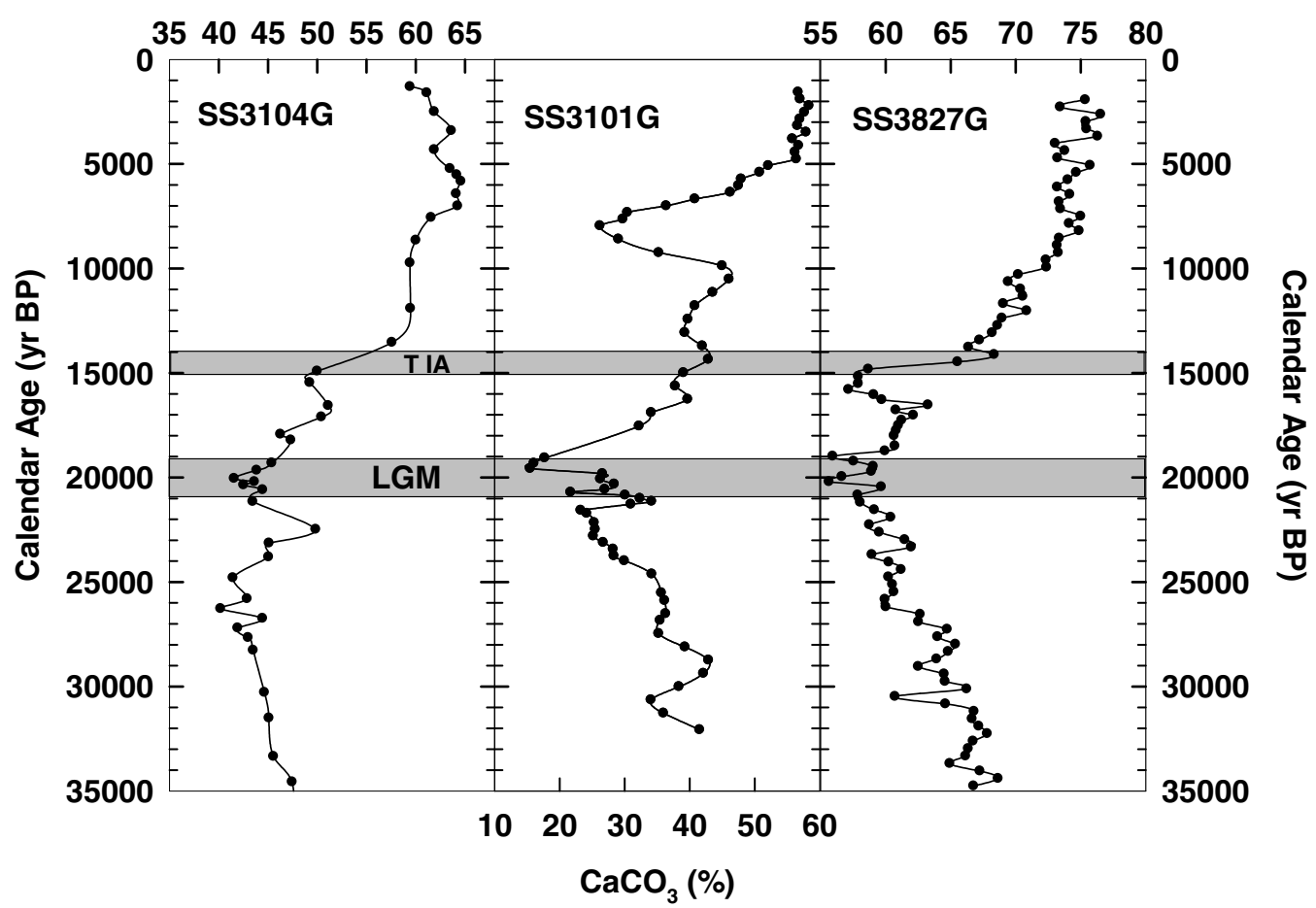

Figure 3 Comparative study of the core SS3827G (last panel; this study) with other cores from eastern Arabian Sea, SS3104G and SS3101G (Agnihotri et al. 2003); LGM and T IA denote last glacial maximum and Termination IA, respectively.

same forcing factor (most probably insolation; Beaufort et al. 1997) governs both. Around 14,500 calendar yr BP, another episode of SWM winds and IEW strengthening are observed as indicated by a sharp increase in the calcareous productivity. During the Holocene, all the cores show a general increase in the calcareous productivity, except for the core SS3101G, which suffers an abrupt decline during 7000-9000 calendar yr BP. This decline is quite intriguing as it is not observed in the cores from the north and south of it due to some local effect that dominates the productivity signal. Agnihotri et al. (2003a) point out that the timing of this decline coincides with the Holocene humid interval, a period of intensified SW monsoon in the Arabian Sea (Sirocko et al. 2000). They speculate that this sharp decline could be due to the build-up of low salinity cover due to an influx of fresh water from the coastal regions that would inhibit upwelling and hence reduce the productivity (Thamban et al. 2001).

Thus, based on the comparative analysis of these 3 cores, we infer that the productivity trends in the eastern and equatorial Arabian Sea were similar (barring some local effects). The IEW and SWM winds strengthened and weakened synchronously due to a common forcing factor.

\section{Sedimentary Organic Matter Not Related to Productivity}

Schulte et al. (1999) have shown that the equatorial Indian Ocean near the core site of SS3827G has remained under oxic conditions for the past 330,000 yr. $\mathrm{C}_{\text {org }}(\%)$ is a traditional proxy for organic productivity (Muller and Suess 1979; Ganeshram et al. 1999; Rixen et al. 2000). On the basis of 
studies carried out on a single giant piston core, MD900963, raised from the equatorial Arabian Sea just east of the Maldives, many colleagues (Bassinot et al. 1994; Beaufort et al. 1997; Rostek et al. 1997; Schulte et al. 1999; Pailler et al. 2002; Schulte and Bard 2003) have proposed that the true representative of overhead surface productivity is $\mathrm{C}_{\text {org }}$ and not the $\mathrm{CaCO}_{3}$ content, which has suffered supralysoclinal dissolution. Apart from $\mathrm{C}_{\mathrm{org}}$, they have measured various other markers, such as microfossil assemblages and molecular species (e.g. $\mathrm{C}_{37}$ alkenone, cholesterol, brassicasterol, $\mathrm{C}_{30}$ keto-ol), based on which they argued that higher productivity was observed during glacial periods, whereas low productivity characterized interglacials. Yet, because of the prevailing oxic conditions, the preservation of organic carbon seems to be very poor, as seen by very low values of $\mathrm{C}_{\text {org }}$ in the present core, with most of the values being less than $0.5 \%$ and in many cases even less than $0.1 \%$. The $\mathrm{C}_{\text {org }}$ preservation is reasonable ( 1\%) only during the LGM. Sarkar et al. (1993) also observed a similar phenomenon, which they ascribed to bottom water anoxia in the eastern/equatorial Arabian Sea based on uranium enrichment, coinciding with an increase in $\mathrm{C}_{\text {org }}$ concentration. Later, Agnihotri et al. (2003b) also recorded a positive excursion in $\mathrm{C}_{\text {org }}$ during the LGM in cores SS3104G and SS3101G (see Figure 1 for location). They also measured redox-sensitive elements, such as $\mathrm{Mn}, \mathrm{Cr}$, $\mathrm{V}$ (normalized to $\mathrm{Al}$ ), to detect past changes in redox conditions but found none, i.e. the water has remained oxic (Schulte et al. 1999). Agnihotri et al. (2003b) proposed that during glacial periods, large areas of continental shelves were exposed due to the fall in sea level. Continental shelves are known to be a major sink of organic carbon and uranium (Borole et al. 1982; Somayajulu et al. 1994). These exposed shelves provided regions of vigorous erosion, and finer particles were advected and redeposited, leading to the observed increase in $\mathrm{C}_{\text {org }}$ and $\mathrm{U}$ during the LGM, as well as enhanced sedimentation. Agnihotri et al. (2003b) found an increased sedimentation rate along with higher concentration and accumulation rate of $\mathrm{Al}$ in the LGM, indicating a supply of clayey material from land. They argue that the enhanced supply of clay and detrital material along with reduced $\mathrm{CaCO}_{3}$ concentration has led to better preservation of $\mathrm{C}_{\text {org }}$, which is also observed by Bhushan et al. (2001 and references therein). Sarkar et al. (1993), though, did not report on this aspect (increased sedimentation rate during the LGM hence more of $\mathrm{U}$ and $\mathrm{C}_{\mathrm{org}}$ ) probably because of poorer chronological control ( ${ }^{14} \mathrm{C}$ dating on bulk sediments).

We also observe a similar pattern in the equatorial Arabian Sea. The sedimentation rate increases at the LGM (inset, Figure 1), which is concurrent with the increase in organic carbon concentration and burial flux. This increase in sedimentation rate is the only factor that led to enhanced $\mathrm{C}_{\text {org }}$ and a sudden jump in $\mathrm{CaCO}_{3}$ burial flux during the LGM (between the 2 crosshairs in Figure 2). Furthermore, $\mathrm{CaCO}_{3}(\%)$ variation has been used by others as an indicator of overhead surface productivity (Sirocko et al. 1993; Naidu and Malmgren 1999; Agnihotri et al. 2003b). Tribovillard et al. (1996) have observed that $\mathrm{C}_{\text {org }}$ enrichment does not correspond to enhanced primary productivity during glacial-interglacial transitions. Others who report enhanced $\mathrm{C}_{\text {org }}$ (and other organic productivity markers) during glacial stages might also be experiencing redeposition of organic material from shelf regions, as their core is also very near to the Maldives coast. Thus, we believe that the $\mathrm{C}_{\text {org }}$ variation at our core site represents preservation rather than overhead surface productivity. The burial flux of organic carbon (Figure 2) closely follows the $\mathrm{C}_{\text {org }}$ concentration, indicating that the factor governing the burial flux is concentration.

The $\mathrm{C} / \mathrm{N}$ ratio is obtained by dividing the $\mathrm{C}_{\text {org }}$ by the nitrogen content of the sedimentary organic matter, which is again very low $(\sim 0.04 \%)$ and has stayed more or less the same throughout the core. Therefore, the $\mathrm{C} / \mathrm{N}$ ratio also exhibits a fluctuation similar to the $\mathrm{C}_{\text {org }}$ variations. 


\section{Carbon Isotopes of Planktonic Foraminifera Unrelated to Productivity}

The carbon isotopic values $\left(\delta^{13} \mathrm{C}\right)$ of planktonic foraminifera are known to be controlled by the $\delta^{13} \mathrm{C}$ of bicarbonate ions present in the seawater (Hoefs 1997). The $\delta^{13} \mathrm{C}$ of the bicarbonate ions, in turn, is controlled by the photic zone organic productivity and the $\delta^{13} \mathrm{C}$ of the water coming from below due to wind-induced mixed-layer deepening or upwelling. $\delta^{13} \mathrm{C}$ was measured in 3 different species of foraminifera (G. ruber, G. sacculifer, G. menardii) and the results are illustrated in Figure 4. The $\delta^{13} \mathrm{C}$ values of the species do not exhibit the same trends shown by calcareous productivity (such as a minimum at the LGM with a sharp increase at $\sim 15,000 \mathrm{cal}$ yr BP). One possible reason for such behavior by $\delta^{13} \mathrm{C}$ is that 2 competing processes (productivity and upwelling) govern it. During enhanced winds, productivity increases due to the influx of nutrients from below, resulting in the consumption of more of ${ }^{12} \mathrm{C}$ by the phytoplanktons, thus increasing the $\delta^{13} \mathrm{C}$ of $\mathrm{HCO}_{3}{ }^{-}$dissolved in the seawater. However, the increased winds also enhance upwelling and bring the water from a deeper level where $\mathrm{HCO}_{3}{ }^{-}$is depleted in $\delta^{13} \mathrm{C}$. (Typically, water from a depth of $100 \mathrm{~m}$ is depleted in $\delta^{13} \mathrm{C}$ by $0.5 \%$ orelative to surface and increases to $1 \%$ oy $\sim 600 \mathrm{~m}$ [Kroopnick 1985].) This upwelled, $\delta^{13} \mathrm{C}$-depleted water essentially nullifies the enrichment due to productivity and thus reduces the signal. The core site lies in the equatorial upwelling zone and is also influenced by the wind-induced mixed-layer deepening. When productivity is higher due to stronger winds, surface mixing and upwelling are also higher, resulting in a mixed signal as discussed above. $\delta^{13} \mathrm{C}$ can be used as a productivity signal in those regions only where the productivity signal is so strong that it masks the upwelling effect, such as in the western Arabian Sea.

\section{SPECTRAL ANALYSIS}

Spectral analysis was carried out on the time-series data of various proxies to detect the underlying inherent periodicities that might point towards the various forcing factors governing the climatic conditions at the core site. The proxies that were analyzed included $\delta^{18} \mathrm{O}$ in all 3 species of foraminifera, along with the $\mathrm{CaCO}_{3} \%$ using the REDFIT 3.6 program (Schulz and Mudelsee 2002). In this region, oxygen isotopes of planktonic foraminifera depict E-P (evaporation-precipitation) balance after accounting for ice-volume effect and sea surface temperature changes (Rostek et al. 1993), which have been discussed elsewhere (Tiwari et al. 2005a,b). Proxies such as $\mathrm{C}_{\text {org }}$ content and $\delta^{13} \mathrm{C}$ were excluded from this exercise, as their variations do not truly represent the changes in overhead productivity as discussed above. The various spectra that were obtained are shown in Figure 5. The $\delta^{18} \mathrm{O}$ spectrum of the foraminiferal species G. sacculifer and G. ruber are dominated by a 17,000-yr periodicity, which is very close to the 19,000-yr cycle observed for Earth's precessional cycle. Various other authors (e.g. Clemens et al. 1991; Reichert et al. 1997; Leuschner and Sirocko 2003) have proposed that in the tropics the precessional phase $(\sim 23 \mathrm{kyr})$ dominates the $\mathrm{SW}$ monsoon and associated phenomenon. For example, Reichert et al. (1997) have shown that the $\mathrm{C}_{\mathrm{org}}$ spectrum is dominated by the 23-kyr periodicity, while Ti/Al shows both 100- and 23-kyr periodicities. Beaufort et al. (1997) have noticed that the primary productivity record from the equatorial Arabian Sea in core MD 900963 is strongly dominated by the precession cycles of the 23- to 19-kyr periods. This led them to propose that the productivity variation at the core site is mainly governed by insolation. The $\delta^{18} \mathrm{O}$ spectrum of the G. ruber also exhibits a periodicity of $\sim 9700 \mathrm{yr}$, which seems to be a subcycle of the 19-kyr precession cycle. This result reinforces the idea that the SW monsoon (since $\delta^{18} \mathrm{O}$ variations are mainly influenced by the evaporation-precipitation budget) is mainly governed by the insolation variations induced by the precessional cycle of Earth's orbit.

A time-series analysis of the $\mathrm{CaCO}_{3}$ data exhibits a significant periodicity of $\sim 1140 \mathrm{yr}$, which is similar to the $1470 \pm 500$-yr periodicity observed in records from different locations around the globe 


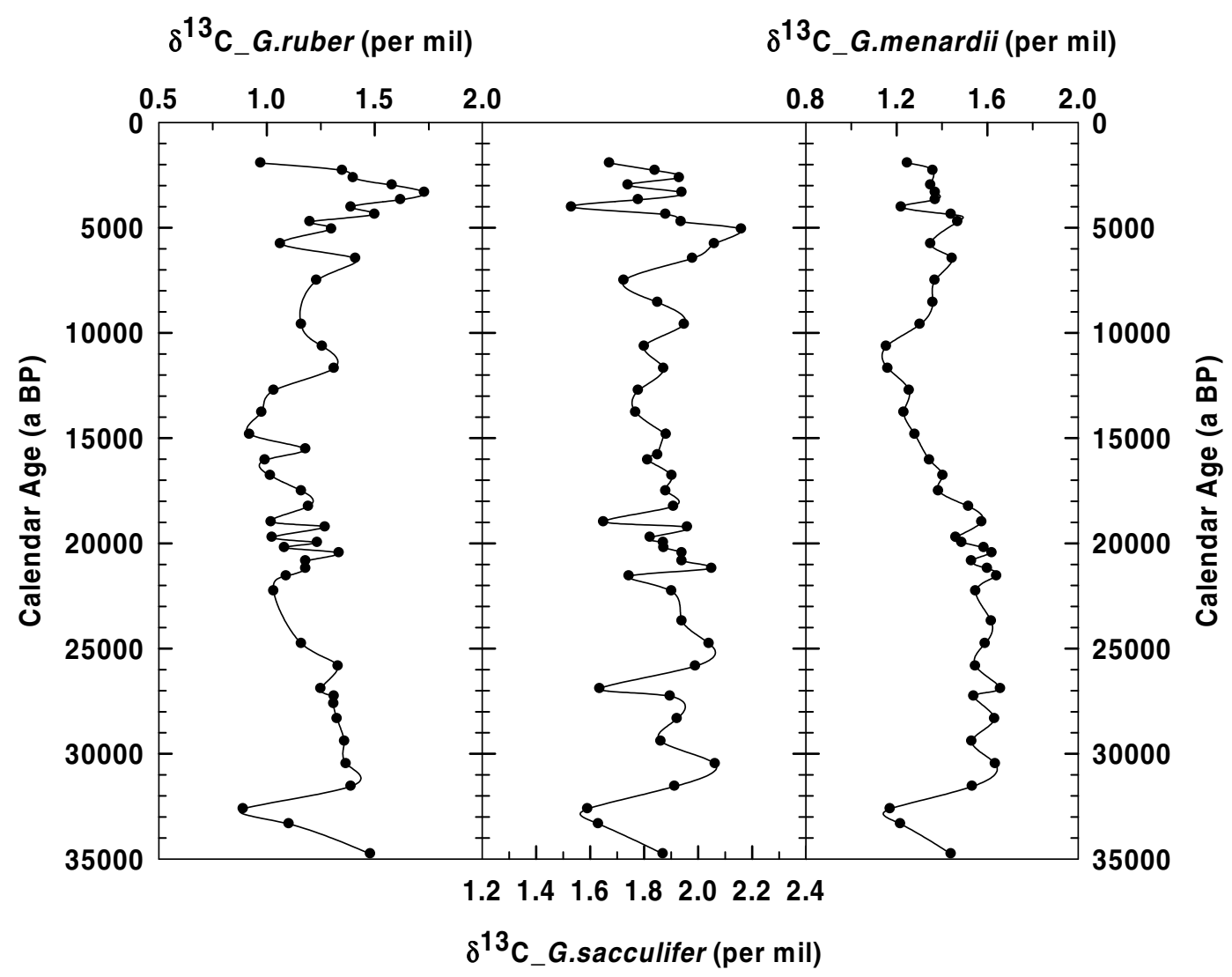

Figure 4 Downcore variation of $\delta^{13} \mathrm{C}$ (relative to VPDB) values of 3 species of planktonic foraminifera in core SS3827G

(Sirocko et al. 1996; Bond et al. 1997; Schulz et al. 1998; Mayewski et al. 1998; Campbell et al. 1998; Agnihotri et al. 2003a). Grootes and Stuiver (1997) have shown that this 1470-yr cycle is exhibited by Dansgaard-Oeschger (D-O) events in the Greenland ice-core $\delta^{18} \mathrm{O}$ record, which occur every $\sim 1400 \mathrm{yr}$. The similar periodicity seen in our equatorial record points towards a common forcing factor that appears to corroborate a common link between the tropical and north Atlantic climate. A time-series analysis of $\delta^{18} \mathrm{O}$ in G. menardii does not yield any periodicity; this might be due to the fact that this species dwells in deeper water and hence is mildly affected by the E-P budget that mainly controls the $\delta^{18} \mathrm{O}$ variations at the core site.

\section{CONCLUSION}

Calcareous productivity indicates a decreasing IEW and hence decreasing Indian and east African rainfalls from 35,000 calendar yr BP up to the LGM, with a minimum value at the LGM, indicating a maximum El Niño frequency during the last glacial period. Thereafter, the IEW strengthened until 16,500 calendar yr BP, after which it fell back sharply to LGM values for a millennium $(\sim 15,500$ calendar yr BP), thus signalling a reduction in Indian and African rainfalls. Subsequently, the IEW sharply increased at $\sim 14,500$ calendar yr BP (coinciding with the Termination IA), implying a strengthened SWM and EAR. Since $\sim 14,500$ to 2200 calendar yr BP, including the Holocene, calcareous productivity uniformly increased, signifying a uniform strengthening of the IEW and SOI and hence stronger SWM and EAR along with declining El Niño frequency. Based on the compar- 

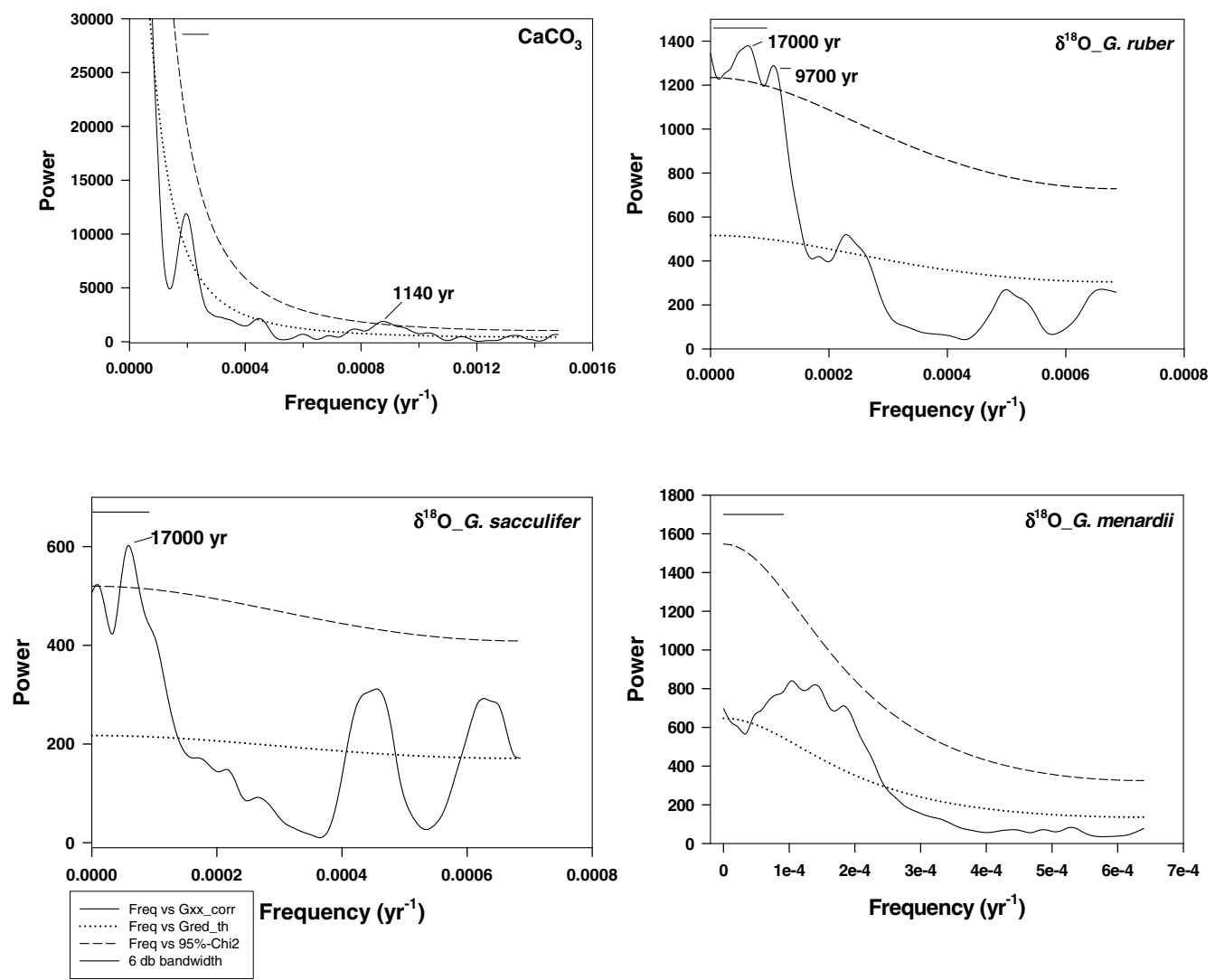

Figure 5 Power spectra for various paleoclimatic proxies. Horizontal line in the upper left-hand corner represents 6-db bandwidth of the spectral resolution. Gxx_corr denotes amplitude or power of various frequencies; Gred_th (dotted line) is the background signal, while the dashed line denotes the $95 \%$ significance level calculated using the $\chi^{2}$ test.

ative study from the other 2 cores from the eastern Arabian Sea, it could be inferred that the IEW and SW monsoon winds strengthened and weakened in unison, pointing towards a common forcing factor, most probably insolation, at least during the last 35,000 calendar yr BP. $\delta^{13} \mathrm{C}$ of the foraminifera also is not useful as a productivity indicator, as the signal is mixed due to upwelling and productivity. Spectral analyses of various proxies indicate that the SW monsoon is dominated by the quasiperiod of the precessional cycle, which indicates that it is governed by solar forcing on the Milankovitch time scale. Common periodicity between the equatorial and north Atlantic records points towards a possible common mechanism linking them.

\section{ACKNOWLEDGMENTS}

We thank the Indian Space Research Organization Geosphere Biosphere Program for funding.

\section{REFERENCES}

Agnihotri R, Bhattacharya SK, Sarin MM, Somayajulu BLK. 2003a. Changes in the surface productivity and subsurface denitrification during the Holocene: a multiproxy study from the eastern Arabian Sea. The Ho- locene 13:701-13.

Agnihotri R, Sarin MM, Somayajulu BLK, Jull AJT, Burr GS. 2003b. Late-Quaternary biogenic productivity and organic carbon deposition in the eastern Ara- 
bian Sea. Palaeogeography, Palaeoclimatology, Palaeoecology 197:43-60.

Bassinot FC, Beaufort L, Vincent E, Labeyrie LD, Rostek F, Müller PJ, Quidelleur X, Lancelot Y. 1994. Coarse fraction fluctuations in pelagic carbonate sediments from the tropical Indian Ocean: a 1500-kyr record of carbonate dissolution. Paleoceanography 9(4):579-600.

Beaufort L, Lancelot Y, Camberlin P, Cayre O, Vincent E, Bassinot F, Labeyrie L. 1997. Insolation cycles as a major control of equatorial Indian Ocean primary production. Science 278:1451-4.

Beltrando G, Camberlin P. 1993. Interannual variability of rainfall in the eastern Horn of Africa and indicators of atmospheric circulation. International Journal of Climatology 13:533-46.

Bhatt US. 1989. Circulation regimes of rainfall anomalies in the African-South Asian monsoon belt. Journal of Climate 2:489-97.

Bhushan R, Dutta K, Somayajulu BLK. 2001. Concentrations and burial fluxes of organic and inorganic carbon on the eastern margins of the Arabian Sea. Marine Geology 178:95-113.

Bjerkness J. 1969. Atmospheric teleconnections from the equatorial Pacific. Monthly Weather Review 97:16372.

Bond G, Showers W, Cheseby M, Lotti R, Alamasi P, deMenocal P, Priore P, Cullen H, Hajdas I, Bonani G. 1997. A pervasive millennial-scale cycle in North Atlantic Holocene and glacial climates. Science 278: 1257-66.

Borole DV, Krishnaswami S, Somayajulu BLK. 1982. Uranium isotopes in rivers, estuaries and adjacent coastal sediments of western India: their weathering, transport and oceanic budget. Geochimica et Cosmochimica Acta 46:125-37.

Campbell ID, Campbell C, Apps MJ, Rutter NW, Bush ABG. 1998. Late Holocene $\sim 1500$ yr climate periodicities and their implications. Geology 26:471-3.

Clemens S, Prell WL, Howard WR. 1987. Retrospective dry bulk density estimates from southeast Indian Ocean sediments: comparison of water loss and chloride-ion methods. Marine Geology 76:57-69.

Clemens S, Prell WL, Murray D, Shimmield G, Weedom G. 1991. Forcing mechanisms of the Indian Ocean monsoon. Nature 353:720-5.

Dansgaard W, Johnsen SJ, Clausen HB, Dahl-Jensen D, Gundestrup NS, Hammer CU, Hvidberg CS, Steffensen JP, Sveinbjörnsdóttir AE, Jouzel J, Bond G. 1993. Evidence for general instability of past climate from a 250-kyr ice-core record. Nature 364:218-20.

Dutta K, Bhushan R, Somayajulu BLK. 2001. $\Delta$ R correction values for the northern Indian Ocean. Radiocarbon $43(2 \mathrm{~A})$ :483-8.

Ganeshram RS, Calvert SE, Pederson TF, Cowie GA. 1999. Factors controlling the burial of organic carbon in laminated and bioturbated sediments off NW Mex- ico: implications for hydrocarbon preservation. Geochimica Cosmochimica Acta 63:1723-34.

Grootes PM, Stuiver M. 1997. Oxygen 18/16 variability in Greenland snow and ice with $10^{-3}$ to $10^{5}$-year time resolution. Journal of Geophysical Research C102: 26,455-70.

Grootes PM, Stuiver M, White JWC, Johnsen S, Jouzel J. 1993. Comparison of oxygen isotope records from the GISP2 and GRIP Greenland ice cores. Nature 366: 552-4.

Gupta AK, Anderson DM, Overpeck JT. 2003. Abrupt changes in the Asian southwest monsoon during the Holocene and their links to the North Atlantic Ocean. Nature 421:354-7.

Hastenrath SL, de Castro L, Aceituno P. 1987. The Southern Oscillation in tropical Atlantic sector. Contributions to Atmospheric Physics 60:447-63.

Hastenrath SL, Nicklis A, Greischar G. 1993. Atmospheric-hydrospheric mechanisms of climate anomalies in the western equatorial Indian Ocean. Journal of Geophysical Research 98(C11):20,219-35.

Hoefs J. 1997. Stable Isotope Geochemistry. 4th edition. Berlin: Springer-Verlag. 41 p.

Jull AJT, Donahue DJ, Linick TW. 1989. Carbon-14 activities in recently fallen meteorites and Antarctic meteorites. Geochimica Cosmochimica Acta 53:2095100.

Kroopnick PM. 1985. The distribution of ${ }^{13} \mathrm{C}$ of $\Sigma \mathrm{CO}_{2}$ in the world oceans. Deep-Sea Research 32:75-84.

Leuschner DC, Sirocko F. 2003. Orbital insolation forcing of the Indian monsoon: a motor for global climate changes? Palaeogeography, Palaeoclimatology, Palaeoecology 197:83-95.

Linick TW, Jull AJT, Toolin LJ, Donahue DJ. 1986. Operation of the NSF Arizona facility for radioisotope analysis and results from selected collaborative research projects. Radiocarbon 28(2A):522-33.

Mackenzie T. 1980. Global carbon cycle: some minor sinks for $\mathrm{CO}_{2}$. Reports of the workshop "Flux of Organic Carbon by Rivers to the Oceans." 21-25 September 1980. Woods Hole, USA.

Martarira CH. 1990. Drought over Zimbabwe in a regional and global context. International Journal of Climatology 10:609-25.

Mayewski PA, Meeker LD, Twickler MS, Whitlow S, Yang Q, Prentice M. 1998. Major features and forcing of high-latitude Northern Hemisphere atmospheric circulation using 110,000-year-long glaciochemical series. Journal of Geophysical Research 102:345-66.

McIntyre A, Molfino B. 1996. Forcing of Atlantic equatorial and subpolar millennial cycles by precession. Science 274:1867-70.

Meyers PA. 1994. Preservation of elemental and isotopic source identification of sedimentary organic matter. Chemical Geology 114:289-302.

Morrill C, Overpeck JT, Cole EJ. 2003. A synthesis of abrupt changes in the Asian summer monsoon since 
the last deglaciation. The Holocene 13:465-76.

Muller PJ, Suess E. 1979. Productivity, sedimentation rate and sedimentary organic matter in the oceans-I: organic carbon preservation. Deep-Sea Research 26: 1347-62.

Naidu PD, Malmgren BA. 1999. Quaternary carbonate record from the equatorial Indian Ocean and its relationship with productivity changes. Marine Geology 161:49-62.

O'Brien JJ, Hulburt HE. 1974. Equatorial jet in the Indian Ocean: theory. Science 184:1075-7.

Ogallo LJ, Janowiak JE, Halpert MS. 1998. Teleconnection between seasonal rainfall over east Africa and global surface temperature anomalies. Journal of the Meteorological Society of Japan 66(6):807-21.

Pailler D, Bard E, Rostek F, Zheng Y, Mortlock R, van Geen A. 2002. Burial redox-sensitive metals and organic matter in the equatorial Indian Ocean linked to precession. Geochimica et Cosmochimica Acta 66(5): 849-65.

Pant GB, Parthasarathy B. 1981. Some aspects of an association between the Southern Oscillation and Indian summer monsoon. Archiv für Meteorologie, Geophysik und Bioklimatologie 29(B):245-51.

Peterson LC, Prell WL. 1985. Carbonate dissolution in recent sediments of the eastern equatorial Indian Ocean: preservation patterns and carbonate loss above the lysocline. Marine Geology 64:259-90.

Premuzic ET, Benkovitz CM, Gaffney JS, Walsh JJ. 1982. The nature and distribution of organic matter in the surface sediments of the world oceans and seas. Organic Chemistry 4:63-77.

Ramesh R, Tiwari M. 2005. Significance of stable oxygen $\left(\delta^{18} \mathrm{O}\right)$ and carbon $\left(\delta^{13} \mathrm{C}\right)$ isotopic compositions of individual foraminifera $(O$. universa) in a sediment core from the eastern Arabian Sea. In: Sinha DK, editor. Micropaleontology: Application in Stratigraphy \& Paleoceanography. New Delhi: Narosa. p 309-30.

Rasmusson EM, Carpenter TH. 1983. The relationship between eastern equatorial Pacific sea surface temperature and rainfall over India and Sri Lanka. Monthly Weather Review 111:517-28.

Reichert GJ, Dulk MD, Visser HJ, van der Weijden CH, Zachariasse WJ. 1997. A 225 kyr record of dust supply, paleoproductivity and the oxygen minimum zone from the Murray Ridge (northern Arabian Sea). Palaeogeography, Palaeoclimatology, Palaeoecology 134:149-69.

Reverdin G, Cadet DL. Gutzler D. 1986. Interannual displacement of convection and surface circulation over the equatorial Indian Ocean. Quarterly Journal of the Royal Meteorological Society 112:43-67.

Rixen T, Ittekkot B, Gaye BH, Schafer P. 2000. The influence of the SW monsoon on the deep-sea organic carbon cycle in the Holocene. Deep-Sea Research II 47:2629-51.

Ropelewski CF, Halpert MS. 1987. Global and regional scale precipitation patterns associated with the El Niño/Southern Oscillation. Monthly Weather Review 115:1606-26.

Rostek F, Ruhland G, Bassinot FC, Muller PJ, Labeyrie LD, Lancelot Y, Bard E. 1993. Reconstructing sea surface temperature and salinity using $\delta^{18} \mathrm{O}$ and alkenone records. Nature 364:319-21.

Rostek F, Bard E, Beaufort L, Sonzogni C, Ganssen G. 1997. Sea surface temperature and productivity records for the past $240 \mathrm{kyr}$ in the Arabian Sea. DeepSea Research II 44:1461-80.

Sarkar A, Bhattacharya SK, Sarin MM. 1993. Geochemical evidence for anoxic deep water in the Arabian Sea during the last glaciation. Geochimica et Cosmochimica Acta 57:1009-16.

Sarkar A, Ramesh R, Somayajulu BLK, Agnihotri R, Jull AJT, Burr GS. 2000. High resolution Holocene monsoon record from the eastern Arabian Sea. Earth and Planetary Science Letters 177:209-18.

Schott FA, McCreary Jr JP. 2001. The monsoon circulation of the Indian Ocean. Progress in Oceanography 51:1-123.

Schulte S, Bard E. 2003. Past changes in biologically mediated dissolution of calcite above the chemical lysocline recorded in Indian Ocean sediments. Quaternary Science Reviews 22:1757-70.

Schulte S, Rostek F, Bard E, Rullkotter J, Marchal O. 1999. Variations of oxygen-minimum and primary productivity recorded in sediments of the Arabian Sea. Earth and Planetary Science Letters 173:205-21.

Schulz M, Mudelsee M. 2002. Estimating red-noise spectra directly from unevenly spaced paleoclimatic time series. Computers and Geosciences 28:421-6.

Schulz H, von Rad U, Erlenkeuser H. 1998. Correlation between Arabian Sea and Greenland climate oscillations of the past 110,000 years. Nature 393:54-7.

Sirocko F, Sarnthein M, Erlenkreuser H, Lange H, Arnold M, Duplessy JC. 1993. Century-scale events in monsoon climate over the past 24,000 years. Nature 364:322-4.

Sirocko F, Garbe-Schönberg D, McIntyre A, Molfino B. 1996. Teleconnections between the subtropical monsoons and high-latitude climates during the last deglaciation. Science 272:526-9.

Sirocko F, Garbe-Schönberg D, Devey C. 2000. Processes controlling trace element geochemistry of Arabian Sea sediments during the last 25,000 years. Global and Planetary Change 26:217-303.

Somayajulu BLK, Yadav DN, Sarin MM. 1994. Recent sedimentary records from the Arabian Sea. Proceedings of Indian Academy of Science 103:315-27.

Southon J, Kashgarian M, Fontugne M, Metivier B, Yim W-S Wyss. 2002. Marine reservoir corrections for the Indian Ocean and Southeast Asia. Radiocarbon 44(1): $167-80$.

Stuiver M, Reimer PJ, Bard E, Beck JW, Burr GS, Hughen KA, Kromer B, McCormac G, van der Plicht 
J, Spurk M. 1998. IntCa198 radiocarbon age calibration, 24,000-0 cal BP. Radiocarbon 40(3):1041-83.

Thamban M, Rao VP, Schneider RR, Grootes PM. 2001. Glacial to Holocene fluctuations in hydrography and productivity along the southwestern continental margin of India. Palaeogeography, Palaeoclimatology, Palaeoecology 165:113-27.

Tiwari M, Ramesh R, Somayajulu BLK, Jull AJT, Burr GS. 2005a. Early deglacial ( 19-17 ka) strengthening of the northeast monsoon. Geophysical Research Letters 32(19):L19712, doi: 10.1029/2005GL024070.

Tiwari M, Ramesh R, Somayajulu BLK, Jull AJT, Burr GS. 2005b. Paleomonsoon precipitation deduced from a sediment core from the equatorial Indian Ocean. Geo-Marine Letters: doi: 10.1007/s00367-00500120 .
Tribovillard N-P, Caulet J-P, Vergnaud-Grazzini C, Moureau N, Tremblay P. 1996. Lack of organic matter accumulation on the upwelling-influenced Somalia Margin in a glacial-interglacial transition. Marine Geology 133:157-82.

Van Heerden J, Terblancke E, Schulze GC. 1988. The Southern Oscillation and South African rainfall. Journal of Climatology 8:577-97.

Walker TN. 1990. Links between South African summer rainfall and temperature variability of the Agulhas and Benguela current systems. Journal of Geophysical Research 95(C3):3297-319.

Wrytki K. 1973. Physical oceanography of the Indian Ocean. In: Zeitzschel B, editor. The Biology of the Indian Ocean. New York: Springer-Verlag. p 18-36. 